\title{
Investigating the Cytotoxic and Anti-Bacterial Activity of Commercially Available Local Anesthetics: An In-Vitro Analysis
}

\author{
Eisha Imran ${ }^{1}$ \\ BDS \\ Faisal Moeen ${ }^{2}$ \\ BDS, MSc \\ Humayoon Satti ${ }^{3}$ \\ PhD \\ Lubna Rahman ${ }^{4}$ \\ M.Phil
}

OBJECTIVE: To evaluate and compare the influence of three local anesthetic dental formulations manufactured in France (Septodont), Korea (Medicaine) and Pakistan (HD-Caine) in terms of cytotoxicity and anti-bacterial activities. METHODOLOGY: 90 commercially available local anesthetic cartridges of similar composition ( $2 \%$ lidocaine with epinephrine $100,000)$ viz. Septodont, Medicaine and HD-Caine were randomly collected from three different Pakistani cities and were assigned as Group S, Group M and Group H, respectively. The cartridges were further divided into three sub-groups each consisting of 10 cartridges to first evaluate cytotoxicity on Mesenchymal Stem Cells (MSCs) using a flow cytometer and secondly to investigate anti-bacterial activity by measuring zones of inhibition and through Broth Dilution Method against five bacterial strains.

RESULTS: The results indicated that Septodont $(94.5 \pm 0.1)$ and Medicaine $(94.7 \pm 0.0)$ showed the highest viability percentage with no significant difference when the two were compared ( $\mathrm{P}=0.6)$. HD-Caine (93.9 \pm 0.0$)$ showed the least, being significantly $(\mathrm{P}<0.01)$ different from Septodont and Medicane. A statistically significant $(\mathrm{P} \leq 0.05)$ difference was identified between the three study groups regarding the anti-bacterial activity. HD-Caine showed the highest anti-bacterial potential, followed by Medicaine and Septodont.

CONCLUSION: Mild toxicity was observed by all the three groups in human MSCs, justifying their safe use in clinical practice. Additionally, Medicane and HD-Caine showed significant anti-bacterial activity indicating their possible use as sterile irrigants. KEYWORDS: Dental anesthesia, Lidocaine, Epinephrine, Antibacterial activity

HOW TO CITE: Imran E, Moeen F, Satti H, Rahman L. Investigating the cytotoxic and anti-bacterial activity of commercially available local anesthetics: An in-vitro analysis. J Pak Dent Assoc 2020;29(4):185-192.

DOI: https://doi.org/10.25301/JPDA.294.185

Received: 02 June 2020, Accepted: 28 July 2020

\section{INTRODUCTION}

$\mathrm{L}$ ocal anesthesia laid the foundation for pain management techniques in dentistry. ${ }^{1}$ and is indicated in almost every dental procedure as it provides numbness to both hard and soft tissues of the oral cavity resulting in insensibility to pain while the patient remains conscious. Comparably secure and standardized anesthetic solutions are utilized these days but still these solutions require exploration, with an aspiration of bringing an innovation, which would enhance the beneficial effects and

1. Postgraduate Trainee, Department of Dental Materials, Riphah International University, Islamic International Dental College.

2. Associate Professor, Department of Dental Materials, Riphah International University, Islamic International Dental College.

3. Assistant Professor, Department of Biological Sciences, National University of Medical Sciences.

4. PhD Scholar, Department of Biotechnology, Quaid-e-Azam University

Corresponding author: "Dr. Eisha Imran” < eishaimran@ ymail.com > diminish the adverse effects of these compulsory drugs. Drugs used in these solutions may notably intrude with the normal physiological processes of the body, causing local and systemic side effects. "Pain at injection site $^{2}$, pungent taste $^{3}$, lack of desired effect due to inappropriate anesthetic technique ${ }^{4}$, ulceration and induced infection at sites of injection are the few local complications.

Systemic complications such as toxicity develop when toxic concentration of local anesthetic. Loss of consciousness and respiratory depression are few of its initial symptoms. Literature mentions the toxic effects of local anesthetics on different tissues, for example fibroblast, articular chondrocytes, human leukocyte and corneal endothelial cells, ${ }^{5-9}$ thus challenging their safety use. Therefore, an interrogation to check and compare the cytotoxic effects of locally available pharmaceutical solutions was required. Numerous in-vitro cytotoxic studies have been published on local anesthesia to assess their effects on cell viability 
using mammalian cell lines. ${ }^{7,10}$ Breu et al and Eckl et al studied the relationship of the viability of MSCs to the time of exposure at different concentrations of local anesthetic agents and deduced that MSC's viability depends on the local anesthetic agent used, its concentration and the time of exposure. Cell viability was evaluated using Annexin-V stain and results were analyzed quantitatively using a flow cytometer. ${ }^{11}$ Another novel finding by Oliveira et al and Roderguez et al concluded apoptosis linked cell death and the detrimental effects of lidocaine when exposed to oral mucosa fibroblast; cells that are significantly involved in wound healing. ${ }^{12}$ Studies showed that lidocaine when used alone or in combination with other agents reported most adverse reactions. ${ }^{13}$ Likewise, studies documented the association of adverse effects with the preservatives used along with the local anesthetic agent like sulfite and hydrochloric acid. ${ }^{14}$

Practitioners need to emphasize on epinephrine's indications and contraindications before using on patients especially the ones who are immunocompromised. The extensive use of epinephrine is linked with its ability to slow down the systemic absorption of the local anesthetic agent, resulting in lower plasma levels of the drug involved. However, they have potential to cause local and systemic reactions. Necrosis and ischemia of the nearby tissues are the local complications. Systemic complications include cardiovascular changes like palpitations and dysrhythmias. ${ }^{13}$ A clinician should take a proper history before administrating a local anesthetic. Reduced tolerance to local anesthetics has been reported in patients suffering from heart problems, thyroid dysfunction, anemia and diabetes. Drug clearance should be considered by the dentist before injecting lidocaine as it's an amide and metabolized by the liver.

Multitudinous in-vitro and in-vivo investigations have also assessed anti-microbial effects of local anesthetics, mostly showing positive activity and its advantageous implications during a number of clinical scenarios. ${ }^{15-19}$ Over the preceding years, anti-microbial activity of anesthetics allured surveillance by research teams. Aydin et al and Eyigort et al compared the anti-microbial activity of different anesthetic agents using Broth Dilution Method, their results revealed that lidocaine and prilocaine had strong antimicrobial activity in contrast to bupivacaine. ${ }^{20}$ Kesici et al established the correlation between the combined antimicrobial effects of local anesthetics and vasoconstrictors. They performed these in-vitro approaches using disk diffusion method followed by MIC method and concluded that adrenaline has no anti-microbial properties of its own, however when used in combination with lidocaine, showed higher anti-bacterial potential. ${ }^{21}$

Considering that cytotoxicity and anti-microbial activity are important parameters for LA solutions and since no available literature addressing these properties is available for the most commonly used local anesthetic options in Pakistan, the objective of this investigation was to investigate and compare toxicity effects on cell lines from a Pakistani donor and anti-bacterial activity of lidocaine and epinephrine, manufactured by two international brands (Septodont and Medicaine) and one recently launched Pakistani manufactured LA solution (HD-Caine). The significance of exploring these parameters might help the safe use of locally manufactured anesthetics, which are generally averted over international brands.

\section{METHODOLOGY}

Three commonly used commercial local anesthetic solutions were selected. Details of these formulations are illustrated in Table 1.

Table 1: Details of the pharmaceutical solutions used in the study

\begin{tabular}{|l|c|l|l|l|c|}
\hline $\begin{array}{c}\text { Sources } \\
\text { (countries) }\end{array}$ & $\begin{array}{c}\text { Number } \\
\text { of } \\
\text { cartridges } \\
\text { used }\end{array}$ & Manufacturer & $\begin{array}{c}\text { Lot } \\
\text { number }\end{array}$ & Active ingredients & $\begin{array}{c}\text { Groups } \\
\text { assigned }\end{array}$ \\
\hline Pakistan & 30 & $\begin{array}{l}\text { HD-Caine, } \\
\text { Sharmaceuticals, } \\
\text { Kot-Lakhpat, } \\
\text { Lahore }\end{array}$ & $\begin{array}{l}\text { D-1903 } \\
\text { D-1816 }\end{array}$ & $\begin{array}{l}\text { Lignocaine HCL 2\% } \\
\text { Epinephrine } \\
\text { (1:100,000) }\end{array}$ & H \\
\hline France & 30 & $\begin{array}{l}\text { Septodont Saint- } \\
\text { Maur-des, }\end{array}$ & 002277 & $\begin{array}{l}\text { Lidocaine } \\
\text { hydrochloride....44mg } \\
\text { Adrenaline....22mcg }\end{array}$ & S \\
\hline Korea & 30 & $\begin{array}{l}\text { Medicaine, } \\
\text { Huons Co.Ltd } \\
\text { Gyeonggi-do, } \\
\text { Korea, Republic }\end{array}$ & GA8127 \\
GA8127 & $\begin{array}{l}\text { Lignocaine HCL } \\
\text { Eming } \\
\text { Epinephrine- } \\
\text { Bitartrate 0.0324mg }\end{array}$ & M \\
\hline
\end{tabular}

\section{Cytotoxicity Assay}

In-vitro cytotoxicity of the three LA solutions was evaluated against bone-marrow derived MSCs from a twentyfour-year-old Pakistani male. These cells were attained from the repository of Air Force Bone Marrow Transplant Center (Islamabad, Pakistan). Cells were cultured in thermo scientific Biolite 130191 vented flask with 500mL high glucose Dulbecco's modified Eagle's medium (DMEM) (Gibco, Denmark) supplemented with $10 \%$ fetal bovine serum (FBS) (Gibco, Denmark) and $200 \mathrm{~L}$ heparin in $500 \mathrm{~mL}$ media. Cells were expanded (Figure 1) at $37^{\circ} \mathrm{C}$ in a humified $5 \%$ $\mathrm{CO}_{2}$ incubator for 5 days. ${ }^{11}$ The MSCs cultures were then exposed to $0.25 \mathrm{~mL}$ sample solutions (Septodont, Medicaine, HD-Caine) and Control (Dulbecco's Phosphate Buffer Saline Solution (PBS) (Gibco, Denmark) for 1 hour. After 1 hour 
of treatment with the local anesthetic solutions, non-adherent MSCs were removed and centrifuged. Cell pellets were washed with Dulbecco's phosphate buffer saline solution (DPBS) (1x). Washing with saline (PBS) removes local anesthesia completely from the cells. Treated cells were again cultured (with DMEM and FBS) and kept overnight

Figure 1: Expanded Mesenchymal Stem Cells at 40x

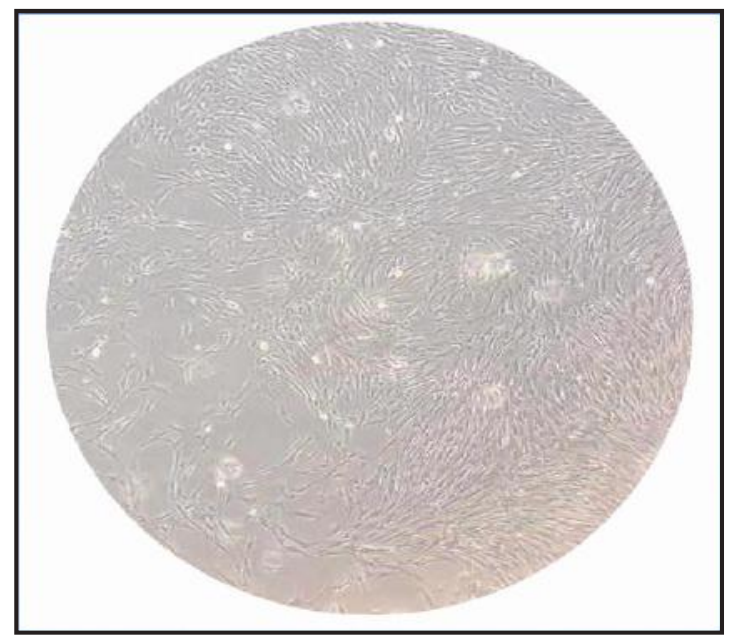

The 7AAD-stain was used to measure cell viability. ${ }^{11}$ after exposure of MSC's to treatment groups for 24 hours. Cell cultures from wells were suspended in eppendorf tubes and centrifuged at $660 \mathrm{G} / 8 \mathrm{~min}$. They were then resuspended in $150 \mathrm{~L}$ volume FACS tubes. A $2 \mathrm{~L}$ of 7AAD stain was added in each FACS tube and incubated in dark for 25 minutes at $25^{\circ} \mathrm{C}$ before acquisition on (Beckman Counter) (NAVIOS) flow cytometer.

\section{Antibacterial activity}

Anti-bacterial activity of $2 \%$ lidocaine with $0.001 \%$ epinephrine in Septodont, Medicaine and HD-Caine along with Negative Control (0.9\% Normal Sterile Saline) $(\mathrm{NaCl})$ (Grow-cells,USA) and Positive Control (20 mL Ampicillin Sodium Salt) (Gibco, Grand Island-New-York) was tested against Staphylococcus aureus ATCC 6538, Bacillus Subtilis ATCC 6633, Pseudomonas aeruginosa ATCC 9721, Klebsiella pneumoniae ATCC 4619, and Staphylococcus epidermidis ATCC 1228. These bacterial strains were attained from stock cultures of Biotechnology Department, Quaid-e-Azam University, Islamabad, Pakistan.

\section{Well-diffusion method}

Tryptic soy broth (TSB) was prepared by autoclaving for 20 mins at $121^{\circ} \mathrm{C}$ to grow fresh cultures of these bacterial strains. The bacteria were inoculated in $10 \mathrm{~mL}$ broth. The inoculated culture was kept in shaking incubator for 24 hours at $37^{\circ} \mathrm{C}$. Test pathogens were swabbed on autoclaved petri dish containing Trypticase soy agar (TSA) media. A sterile borer was used on the surface of TSA plate to make $6 \mathrm{~mm}$ deep wells. The wells were filled with $0.25 \mathrm{~mL}$ of sample solutions, positive control (20 mL Ampicillin Sodium Salt (Gibco, Grand Island-New York) and negative control (0.9\% Normal Sterile Saline $(\mathrm{NaCl})$ (Grow-cells,USA). Subsequently, the plates were then placed in an incubator at $36^{\circ} \mathrm{C}$ for 24 hours. On the following day, Vernier calipers was used to measure the diameter of zones of inhibition. ${ }^{22}$

\section{Broth Dilution Method}

In a tube of TSB, the microbial growth of the five-bacterial species was inoculated and then these tubes were placed in an incubator at $37^{\circ} \mathrm{C}$. A UV/VIS spectrophotometer (SAILAB, AY1708008, AE-S90MD) was used to set the turbidity index such that it equals to McFarland standard $10^{5}$ organisms per mL. $2 \mathrm{ml}$ of all the three local anesthetic solutions (Septodont, Medicaine and HD-Caine) along with positive control (20 mL Ampicillin Sodium Salt (Gibco, Grand Island-New York) and negative control (0.9\% Normal Sterile Saline (NaCl) (Grow-cells,USA) were poured in three different test tubes respectively. Further, $1 \mathrm{~mL}$ of broth culture was introduced in each. Autoclaved, TSA agar plates were used to streak separate samples from the tubes and at that point, calibration of the dilution loop was set to $0.01 \mathrm{~mL}$. The subsequent step was to place these plates in an incubator for 24 hours at $37^{\circ} \mathrm{C}$. The incubated plates were scrutinized for the emergence of bacterial colonies and counted manually. ${ }^{20}$

\section{STATISTICAL ANALYSIS}

Data were analyzed using the Statistical Package for Social Science (SPSS for Windows version 12, SPSS Inc., Chicago, IL, USA). Mean values $( \pm \mathrm{SE}$ ) for various study attributes viz. viability of mesenchymal monolayer cells, inhibitory zone diameter and number of bacterial colonies were calculated. Magnitude of variation of these attributes between three brands i.e. Septodont ${ }^{\circledR}$, Medicaine ${ }^{\circledR}$ and HD-Caine ${ }^{\circledR}$ was ascertained through ANOVA, using completely randomized design (Snedecor and Cochran 1989). Post-hoc Tuckey analysis was implied to detect intergroup differences between mean values. Significance was considered at $\mathrm{P} \leq 0.05$.

\section{RESULTS}

\section{Cytotoxicity}

\section{Analysis of MSC viability using flow cytometer}

Data acquisition for flow cytometry was done using Kaluza analysis software version 2.1. Interpretation of results, 
representing percentage viability are shown in Figure 2 (A) Control (96.85\%), (B) Septodont (94.20\%), (C) Medicaine (94.74\%) and (D) HD-Caine (93.93\%).

$\mathrm{X}$-axis represent 7AAD positive and negative cells while Y-axis represent SS INT (side scatter) representing diversity and phenotype of the cells. From all the cells populated those negative for $7 \mathrm{AAD}$ were gated on $10^{\circ}$, representing viable cells.

Figure 2: Data acquisition representing percentage viability of mesenchymal stem cells after being exposed to (A) Control (B) Septodent (C) Medicaine (D) HD-Caine, using Kaluza software version 2.1

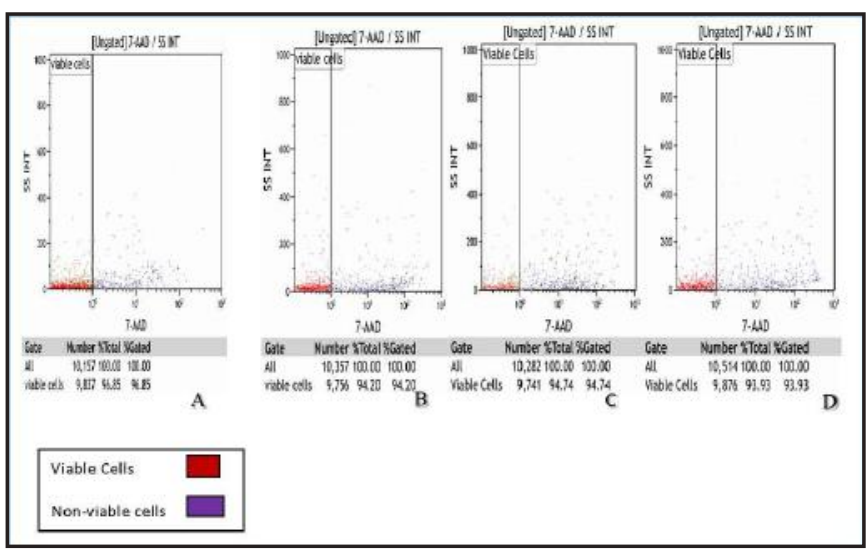

The results of viability obtained from flow cytomter indicated that there was no difference between Septodont $(94.5 \pm 0.1)$ and Medicaine $(94.7 \pm 0.0)(\mathrm{p}=0.6)$ while the viability of HD-Caine was significanlty lesser than both Septodont, Medicaine and Control $(96.6 \pm 0.0)(\mathrm{p}<0.01)$. The mean percentage viablity values are shown in Figure 3,

Figure 3: Percentage viability of mesenchymal stem cells in Septodent, Medicaine and HD-Caine as compared to control

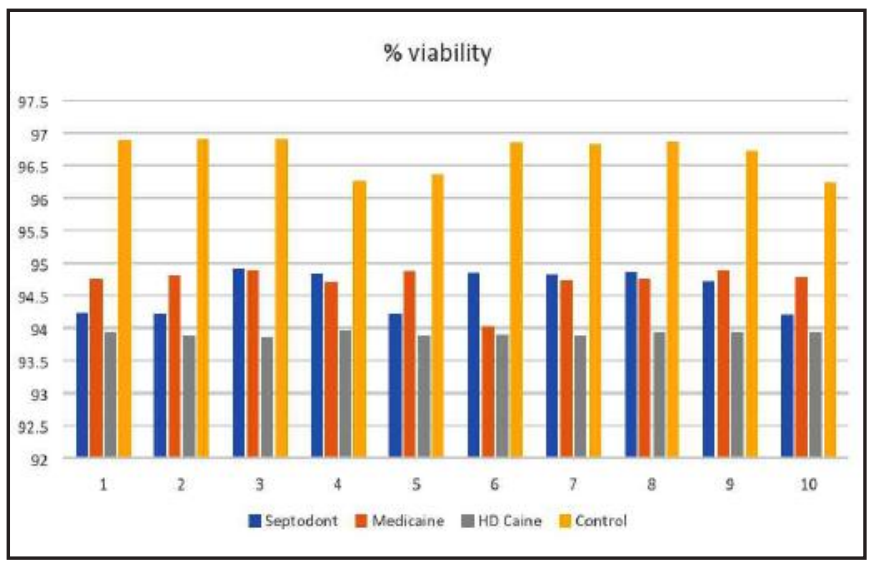

$\mathrm{X}$-axsis represent the number of test solutions used (Septodont, Medicaine, HD-Caine and Control) and Y-axsis represent the viability percentages. Table 2 illustrates intergroup mean differences for viability percentages.
Table 2: Intergroup Mean Difference values, Standard Deviation ( $p$ values) of percentage viability for Septodont, Medicaine, HD-Caine and control

\begin{tabular}{|l|l|l|}
\hline Sample & Comparative sample & Mean difference in viability \\
& Septodont & \\
\cline { 2 - 3 } Control & Medicaine & $2.0 \pm 0.1(0.0)$ \\
\hline \multirow{2}{*}{ Septodont } & HD-Caine & $1.9 \pm 0.1(0.0)$ \\
\hline \multirow{2}{*}{ Medicaine } & Medicaine & $2.7 \pm 0.1(0.0)$ \\
\hline & HD-Caine & $0.1 \pm 0.1(0.6)$ \\
\cline { 2 - 3 } & HD-Caine & $0.6 \pm 0.1(0.0)$ \\
\hline
\end{tabular}

\section{Antibacterial analysis Well-Diffusion method}

The diameter of zones of inhibition formed on different bacterial species when exposed to anesthetic solutions and control solutions are represented in Figure 4. The diameter of these zones was measured using a Vernier calipers. The

Figure 4: Petri dishes displaying zones of inhibition on (A) Staphylococcus aures (B) Klebseilla pneumonia (C) Bacillus subtilis (D) Staphylococcus epidermidis (E) Pseudomonas aeruginosa, when exposed to Septodent (S), Medicaine (M) HD-Caine (H), Positive Control (P.C) and Negative Control (N.C).

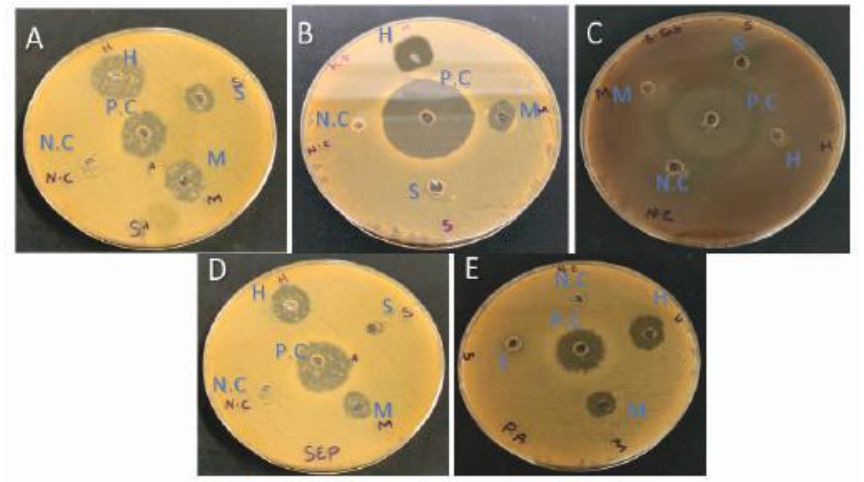

results revealed that Septodont, Medicaine, HD-Caine, Positive and Negative Control showed a significant difference $(\mathrm{p}<0.01)$ against Staphylococcus aureus and Staphylococcus epidermidis. A non-significant difference was shown between Septodont and negative control against Klebsiella pneumonia $(\mathrm{p}=1.0)$, Bacillus subtilis $(\mathrm{p}=1.0)$ and Pseudomonas aeruginosa $(p=1.0)$ while the difference was significant $(p<0.01)$ when compared with rest of the groups (Medicaine, HD-Caine and positive control). The greatest mean diameter after the positive control (antibiotic) was formed by HD-Caine against all the bacterial strains, indicating highest antibacterial activity followed by that for Medicaine while Septodont showed negligible antibacterial activity (Table 3).

\section{Broth Dilution}

Number of bacterial colonies of different bacterial species grown in three groups and control solutions revealed 
Table 3: Comparative mean (SE) values of antibacterial activity for Septodont, Medicaine and HD-Caine

\begin{tabular}{|c|c|c|c|c|c|}
\hline Bacterial species & Septodont & Medicaine & HD-Caine & $\begin{array}{l}\text { Positive } \\
\text { control }\end{array}$ & $\begin{array}{c}\text { Negative } \\
\text { control }\end{array}$ \\
\hline \multicolumn{6}{|c|}{ Inhibitory Zone Diameter (mm) } \\
\hline $\begin{array}{l}\text { Staphylococcus } \\
\text { aureus }\end{array}$ & $2.2 \pm 0.1^{\mathrm{a}}$ & $6.0 \pm 0.1^{\mathrm{b}}$ & $11.4 \pm 0.4^{\mathrm{e}}$ & $7.9 \pm 0.7^{\mathrm{d}}$ & $0^{\circ}$ \\
\hline $\begin{array}{l}\text { Klebsiella } \\
\text { pneumonia }\end{array}$ & $0^{a}$ & $6.8 \pm 0.1^{\mathrm{b}}$ & $12.3 \pm 0.3^{e}$ & $35.3 \pm 0.4^{d}$ & $0^{\mathrm{a}}$ \\
\hline Bacillus subtilis & $0^{a}$ & $13.9 \pm 0.1^{b}$ & $11.6 \pm 0.3^{e}$ & $35.2 \pm 0.2^{d}$ & $0^{\mathrm{n}}$ \\
\hline $\begin{array}{l}\text { Staphylococcus } \\
\text { epidermis }\end{array}$ & $4.1 \pm 0.1^{2}$ & $7.0 \pm 0.1^{b}$ & $12.3 \pm 0.1^{e}$ & $20.1 \pm 0.1^{d}$ & $0^{\circ}$ \\
\hline $\begin{array}{l}\text { Pseudomonas } \\
\text { aeruginosa }\end{array}$ & $0^{\mathrm{a}}$ & $7.9 \pm 0.08^{b}$ & $15.3 \pm 0.1^{\mathrm{e}}$ & $18.1 \pm 0.1^{d}$ & $0^{n}$ \\
\hline \multicolumn{6}{|c|}{ Number of bacterial colonies $\left(\mathrm{CFU}^{-1}\right)$} \\
\hline $\begin{array}{l}\text { Staphylococcus } \\
\text { aureus }\end{array}$ & $209.5 \pm 31.0^{a}$ & $195.9 \pm 1.7^{a}$ & $92.3 \pm 3.2^{b}$ & $0^{\mathrm{e}}$ & $272.5 \pm 10.3^{d}$ \\
\hline $\begin{array}{l}\text { Klebsiella } \\
\text { pneumonia }\end{array}$ & $16.9 \pm 0.5^{a}$ & $11.6 \pm 0.6^{b}$ & $6.8 \pm 0.2^{\mathrm{c}}$ & $0^{d}$ & $57.0 \pm^{e}$ \\
\hline Bacillus subtilis & $39.9 \pm 0.9^{a}$ & $36.4 \pm 1.2^{n}$ & $15.5 \pm 0.5^{b}$ & $0^{c}$ & $121.1 \pm 1.2^{d}$ \\
\hline $\begin{array}{l}\text { Staphylococcus } \\
\text { epidermis }\end{array}$ & $240.3 \pm 15.5^{\prime \prime}$ & $129.4 \pm 0.9^{b}$ & $102.5 \pm 2.0^{b}$ & $0^{\mathrm{c}}$ & $193.6 \pm 2.5^{d}$ \\
\hline $\begin{array}{l}\text { Pseudomonas } \\
\text { aeruginosa }\end{array}$ & $61.4 \pm 3.0^{\mathrm{a}}$ & $24.5 \pm 1.5^{b}$ & $17.7 \pm 1.5^{b}$ & $0^{e}$ & $60.9 \pm 2.0^{\mathrm{a}}$ \\
\hline
\end{tabular}

a,b,c within rows with different superscript letters differ at $\mathrm{P} \leq 0.05$.

Table 4: Intergroup Mean Difference values, Standard Deviation ( $\mathrm{p}$ values) for antibacterial activity for Septodont, Medicaine, HD-Caine and control

\begin{tabular}{|c|c|c|c|c|c|c|}
\hline Samples & \begin{tabular}{|l|}
$\begin{array}{l}\text { Comparative } \\
\text { sample }\end{array}$ \\
\end{tabular} & \begin{tabular}{|l|} 
Mean \\
difference in \\
S. aureus \\
(p value)
\end{tabular} & \begin{tabular}{|l|} 
Mean \\
difference in \\
K.Pnemonia \\
(p value)
\end{tabular} & \begin{tabular}{|l|} 
Mean \\
difference in \\
Bsubtilis \\
(p value) \\
\end{tabular} & \begin{tabular}{|l|} 
Mean \\
difference in \\
S.eppidermis \\
(p value)
\end{tabular} & \begin{tabular}{|l|} 
Mean \\
difference in \\
P.aeruginosa \\
(p value)
\end{tabular} \\
\hline \multicolumn{7}{|c|}{ Inhibitory zone diameter in $\mathrm{mm}$} \\
\hline \multirow{4}{*}{$\begin{array}{l}\text { Positive } \\
\text { control }\end{array}$} & Septodont & $5.7 \pm 0.3(0.0)$ & $35.2+0.3(0.0)$ & $35.2 \pm 0.2(0.0)$ & $15.9 \pm 0.1(0.0)$ & $18.1 \pm 0.1(0.0)$ \\
\hline & Medicaine & $1.9 \pm 0.3(0.0)$ & $28.5 \pm 0.3(0.0)$ & $21.3+0.2(0.0)$ & \begin{tabular}{|l|l}
$13.0 \pm 0.1(0.0)$ \\
\end{tabular} & $10.2 \pm 0.1(0.0)$ \\
\hline & HD-Caine & $3.4 \pm 0.3(0.0)$ & $22.9 \pm 0.3(0.6)$ & $23.6 \pm 0.2(0.0)$ & $7.7 \pm 0.1(0.0)$ & $2.8 \pm 0.1(0.0)$ \\
\hline & N.C & $7.9+0.3(0.0)$ & $35.3 \pm 0.3(0.0)$ & $35.2+1.2(0.0)$ & $20.1 \pm 0.1(0.0)$ & \begin{tabular}{|l}
$18.1+1+1.1(0.0)$ \\
\end{tabular} \\
\hline \multirow{2}{*}{$\begin{array}{l}\text { Negative } \\
\text { control }\end{array}$} & Septodont & $2.2+0.3(0.0)$ & $0.0 \pm 0.3(1.0)$ & $0.0 \pm 0.2(1.0)$ & $4.1 \pm 0.1(0.6)$ & $0.0 \pm 0.1(1.0)$ \\
\hline & Medicaine & $6.0 \pm 0.3(0.0)$ & $6.8 \pm 0.3(0.0)$ & $13.9 \pm 0.2(0.0)$ & \begin{tabular}{|l|}
$7.0 \pm 0.1(0.0)$ \\
\end{tabular} & \begin{tabular}{|l|}
$7.9 \pm 0.1(0.0)$ \\
\end{tabular} \\
\hline & HD-Caine & $11 . A \pm 0.3(0.0)$ & $12.3 \pm 0.3(0.0)$ & $11.6 \pm 0.2(0.0)$ & $12.3 \pm 0.1(0.0)$ & $15.3 \pm 0.1(0.0)$ \\
\hline \multirow[t]{2}{*}{ Septodont } & Medicaine & $3.7 \pm 0.3(0.0)$ & $6.8 \pm 0.4(0.0)$ & $13.9 \pm 0.2(0.0)$ & $2.8+0.1(0.6)$ & \begin{tabular}{|l|}
$7.9 \pm 0.1(0.0)$ \\
\end{tabular} \\
\hline & HD-Caine & $9.1 \pm 0.3(0.0)$ & \begin{tabular}{|l|}
$12.3 \pm 0.4(0.0)$ \\
\end{tabular} & $11.6 \pm 0.2(0.0)$ & $8.2 \pm 0.1(0.6)$ & $153 \pm 0.1(0.0)$ \\
\hline Medicaine & HD-Caine & $5.4 \pm 0.3(0.0)$ & $5.5 \pm 0.4(0.0)$ & $2.3 \pm 0.2(0.0)$ & \begin{tabular}{|l|}
$5.3 \pm 0.1(0.6)$ \\
\end{tabular} & $7.4 \pm 0.1(0.0)$ \\
\hline \multicolumn{7}{|c|}{ Number of bacterial colonies (CFU ${ }^{-1}$ ) } \\
\hline \multirow{4}{*}{$\begin{array}{l}\text { Positive } \\
\text { control }\end{array}$} & Septodont & $209.5 \pm 7.9(0.0)$ & $16.9 \pm 0.6(0.0)$ & $39.9 \pm 1.2(0.0)$ & $240.3 \pm 10.0(0.0)$ & $61.4 \pm 2.7(0.0)$ \\
\hline & Medicaine & $1959 \pm 7.0(0.0)$ & $11.6 \pm 0.6(0.0)$ & $36.4 \pm 1.2(0.0)$ & $129.4 \pm 18.0(0.0)$ & $24.5+2.7(0.0)$ \\
\hline & HD-Caine & $92.3 \pm 7.0(0.0)$ & $6.8 \pm 0.6(0.9)$ & $15.5 \pm 1.2(0.0)$ & $102.2 \pm 10.0(0.0)$ & \begin{tabular}{|l}
$17.7 \pm 2.7(0.0)$ \\
\end{tabular} \\
\hline & N.C & $272.5 \pm 7.0(0.0)$ & $57.0 \pm 0.6(0.0)$ & $121.1 \pm 1.2(0.9)$ & $193.6 \pm 10,0(0,0)$ & $60.9 \pm 2.7(0.0)$ \\
\hline \multirow{3}{*}{$\begin{array}{l}\text { Negative } \\
\text { control }\end{array}$} & Septodont & $63.0 \pm 7.0(0.0)$ & $46.1 \pm 0.7(0.0)$ & $81.2 \pm 1.2(0.0)$ & $46.7 \pm 10.0(0.0)$ & $0.50 \pm 2.7(1.0)$ \\
\hline & Medicaine & $76.6 \pm 7.0(0.0)$ & $45.4 \pm 0.7(0.0)$ & $84.7 \pm 1.2(0.0)$ & $64.2 \pm 10.0(0.0)$ & $36.4+2.7(0.0)$ \\
\hline & HD-Caine & $180.2+7.0(0.0)$ & $50.2+0.7(0.0)$ & $105.6 \pm 1.2(0.0)$ & $91.1 \pm 18.0(0.0)$ & \begin{tabular}{|l}
$43.2+2.7(0.6)$ \\
\end{tabular} \\
\hline
\end{tabular}

\begin{tabular}{|l|l|l|l|l|l|l|}
\hline Septodont & Medicaine & $13.6 \pm 7.0(0.3)$ & $5.3 \pm 0.6(0.0)$ & $3.5 \pm 1.2(0.07)$ & $110.9 \pm 10.0(0.0)$ & $36.9 \pm 2.7(0.0)$ \\
\cline { 2 - 7 } & HD-Caine & $117.2 \pm 7.0(0.0)$ & $10.1 \pm 0.6(0.0)$ & $24.4 \pm 1.2(0.6)$ & $137.8 \pm 10.0(0.0)$ & $43.7 \pm 2.7(0.0)$ \\
\hline Medicaine & HD-Caine & $113.6 \pm 7.0(0.0)$ & $4.8 \pm 0.6(0.9)$ & $20.9 \pm 1.2(0.0)$ & $26.9 \pm 10.0(0.077)$ & $6.8 \pm 2.7(0.1)$ \\
\hline
\end{tabular}

a non-significant difference between Septodont and Medicaine for S.aureus $(\mathrm{p}=0.3)$ and B.subtilius $(\mathrm{p}=0.07)$, while a significant difference was shown between HD-Caine, positive and negative control $(\mathrm{p}<0.01)$ for these two bacterial strains. For S.epidermidis $(\mathrm{p}=0.07)$ and P.aeruginosa $(\mathrm{p}=0.1)$ a nonsignificant difference was found between Medicaine and HD-Caine, however the difference was significant between Septodont, positive and negative control $(\mathrm{p}<0.01)$. K.pneumonia showed a significant difference between all the groups $(\mathrm{p}<0.01)$. Comparative mean values of antibacterial activity by well diffusion and broth dilution method are illustrated in Table 3 while the intergroup differences are represented in Table 4.

\section{DISCUSSION}

Expeditious advancement of pharmaceutical industry constrains the need for screening and conducting biocompatibility tests on the newly launched drugs. The present study aimed at comparing the percentage viability of MSCs after being exposed to the three groups of local dental anesthetics namely Septodont, Medicaine, HD-Caine, and the Control.

The findings of this study regarding percentage viability knot well with the previous literature. Our results revealed that the percentage viability of MSCs decreased after being exposed to all the three groups as compared to control. The highest percentage viability was $94.7 \%$ which was statistically in-significant between Septodont $(94.5 \pm 0.1)$ and Medicaine $(94.7 \pm 0.0)(\mathrm{p}=0.6)$. Even though the lowest percentage viability obtained was for HD-Caine, it should be clarified that this was in comparison to Septodont, Medicaine and Control $(\mathrm{P}<0.01)$. However, $93.9 \%$ of cells did survive when exposed to these cartridges and revealed few toxic effects when compared individually with PBS (control) under the same standardized conditions.

These results were in consensus to the findings of $\mathrm{Wu}$ et al and colleagues, who investigated the effects of anesthetics on MSCs derived from rabbit adipose cells and concluded that $1 \%$ lidocaine showed little toxic effects when compared with other anesthetic agents at different concentrations. ${ }^{10}$ Similarly, Shoshani et al and Berger et al studied the effects of lidocaine along with epinephrine and demonstrated that there was no effect on the viability of adipocytes after being exposed to this combination. ${ }^{23}$ In line with the ideas of Celeste et al and colleagues, it was concluded that toxicity of lidocaine was dose and time-dependent, their study shed light on the fact that at low doses, lidocaine did not effect 
mitochondrial functions of fibroblast of the oral mucosa. ${ }^{12}$ Fedder et al and Beck et al reached a similar conclusion by exposing fibroblast to different anesthetic agents. Their results demonstrated that lidocaine and ropivacaine slightly deformed the cells as compared to bupvicaine, which was more toxic and resulted in greater deformation. ${ }^{6}$

The MSCs are not only involved in wound healing after surgery but they also offer promising clinical applications in the dental world, which signifies that they will be in direct contact with the anesthetics being used. Studies have proved that these cells are sensitive to anesthetics so their safe use demands vigilance by clinicians and researchers. Toxicity of anesthetics is linked to their lipophilicity, thus lidocaine being less lipophilic makes it less toxic when compared to other amide anesthetic agents, validating their secure use in dental practice. ${ }^{10}$ In case of clinical implications, a toxic anesthetic would augment the possibility of oral paresthesia, especially when administrating an inferior alveolar nerve block as studies report $89 \%$ chances of lingual nerve being involved. ${ }^{12,24}$ Secondly, muscular stiffness is also linked to the myotoxic effects of anesthetics resulting in degenerative changes in masseter and medial pterygoid. ${ }^{12,25}$ Another usual post-operative clinical complication, following a palatine block, is the occurrence of palatal ulceration or tissue necrosis, which is caused by anesthetic toxicity or high concentration of vasoconstrictors. ${ }^{26}$

Two limitations in implementing this study design were the use of the same anesthetic agent in the same concentration along with epinephrine, thus higher concentrations of lidocaine could not be evaluated neither estimation of their individual toxic effect was possible. Secondly an exposure time of 1 hour was done to mimic the clinical situations and shed light for practitioners regarding the biocompatibility of the three brands used. From interference of this data, it can be construed that these local anesthetic solutions have mild toxicity but immoderate use of drug via topical or parenteral route can lead to lidocaine toxicity or death. ${ }^{27}$ The FDA mentions standard safe doses and guidelines for safe use of anesthetic agents in clinical practice. For $2 \%$ lidocaine in combination with epinephrine, the maximum dosage is $7 \mathrm{mg} . \mathrm{Kg}^{-1}{ }^{28}$

The framework of the study design for anti-bacterial activity was bisected through two approaches and the findings were contrasted. The outcome of this study corroborated with what was found in the previous studies and all the three groups showed antibacterial activity. ${ }^{19,29,30}$ The findings observed by measuring the diameter of inhibitory zones showed a statistically, significant difference between the three groups $(\mathrm{P}<0.05)$. The highest anti-bacterial activity was observed in HD-Caine, followed by Medicaine while Septodont showed minimum anti-bacterial activity. This method was done as a screening test and the authenticity of these findings were then confirmed by broth dilution method and the number of bacterial colonies formed was counted. This later approach delivered significantly better findings due to its sensitivity. Septodont formed the highest number of bacterial colonies, thus showing the least anti-microbial potential, followed by Medicaine. HD-Caine, on the other hand, formed the least number of bacterial colonies, revealed highest anti-bacterial potential.

A similar deduction was drawn by Kesici et al, that lidocaine, when used in combination with epinephrine, showed anti-bacterial activity on S.aureus, E.coli and P.aeruginosa. His findings further demonstrated that epinephrine has a synergistic effect on lidocaine's antibacterial activity. ${ }^{21}$ The approach used in our study suffered limitation since the cartridges used were in combination with epinephrine, hence the individual anti-bacterial activity of lidocaine and epinephrine could not be concluded. Aydin et al and Eyigort et al compared the anti-bacterial activity of lidocaine with other anesthetic agents such as ropivacaine and proposed that lidocaine has the highest anti-bacterial potential as compared to other local anesthetic agents depending on their concentration and time of exposure..$^{20}$ Selection of bacterial strains was done on the basis of their unique characterization and are the common hospital pathogens. ${ }^{31}$ The significance of Staphylococcus-aureus as a common pathogen has been acknowledged in the literature. Oral cavity infections including 'angular cheilitis ${ }^{32}$, jaw osteomyelitis ${ }^{33}$, mucositis ${ }^{34}$, endodontic infections ${ }^{35}$, parotitis ${ }^{36-38}$ are originated by S.aureus. ${ }^{39}$ Staphylococcalaureus strains are also known to have the potential to spread and colonize to other body parts or might spread to other patients resulting in cross infection. ${ }^{40}$ While, Bacillus subtilis is considered best to be studied for bacterial characterization and has acquired attention as probiotics. ${ }^{41}$ Pseudomonas aeruginosa works by removing the antibiotic from the cell's interior, many antibiotics and disinfectants are ineffective against it. ${ }^{42}$ Klebsiella-pneumoniae, widely known for its antibiotic resistance activity is responsible for majority of infections in hospital and community ${ }^{43}$ and Staphylococcus epidermidis is a cause of most frequent occurring infections as a result of implants and catheters. ${ }^{44}$

The quest of exploring the anti-microbial activity of anesthetics contributes in letting the practitioners determine and differentiate the finest brand of anesthetics that could serve as prophylaxis for treating infectious diseases before a surgical procedure ${ }^{19}$ and which cartridges to be possibly used for irrigation in endodontics. ${ }^{45}$ The anti-microbial property of anesthetic agents augments the probability of false-negative results while obtaining culture specimens for diagnostic procedures ${ }^{46}$ thus for such cases, use of mild 
anesthetic agents at lowest concentration is recommended to optimize the culture yield.

\section{CONCLUSION AND RECOMMENDATIONS}

From a biocompatibility view point, minimal toxic effects were observed in all the test samples when compared with the control at proclaimed $2 \%$ concentration of lidocaine. Significant difference was revealed while assessing antimicrobial activity. Septodont showed the least antibacterial activity while Medicaine and HD-Caine showed the highest anti-microbial potential. For future investigations, MSCs should ideally be exposed to different local anesthetic agents and at different concentrations. Secondly, the type of cell death (necrosis/apoptosis) should also be evaluated using annexin V stain. Investigation of anti-microbial potential of anesthetics using fungal strains especially candida albicans can have additional implication in oral infections.

\section{CONFLICT OF INTEREST}

The authors proclaim no conflict of interest.

\section{FUNDING}

The study was conducted independently without any form of financial or otherwise assistance from any of the product manufacturers, hence free from any form of bias.

\section{REFERENCES}

1. Malamed SF. Local anesthetics: dentistry's most important drugs, clinical update 2006. J Calif Dent Assoc 2006;34:971.

2. Gazal G, Fareed WM, Zafar MS. Effectiveness of gaseous and intravenous inductions on children's anxiety and distress during extraction of teeth under general anesthesia. Saudi J Anaesth. 2015;9:33. https://doi.org/10.4103/1658-354X.146282

3. Wei Y, Nedley MP, Bhaduri SB, Bredzinski X, Boddu SH. Masking the bitter taste of injectable lidocaine $\mathrm{HCl}$ formulation for dental procedures. Aaps Pharmscitech. 2015;16:455-65.

https://doi.org/10.1208/s12249-014-0239-z

4. Gazal G, Fareed W, Zafar M. Role of intraseptal anesthesia for painfree dental treatment. Saudi J Anaesth. 2016;10:81.

https://doi.org/10.4103/1658-354X.169482

5. Yalcin BK. Complications Associated with Local Anesthesia in Oral and Maxillofacial Surgery. Local Anesthetics: IntechOpen; 2019.

6. Fedder C, Beck-Schimmer B, Aguirre J, Hasler M, Roth-Z'graggen $\mathrm{B}$, Urner $\mathrm{M}$, et al. In vitro exposure of human fibroblasts to local anaesthetics impairs cell growth. Clin Exp Immunol. 2010;162:280-8. https://doi.org/10.1111/j.1365-2249.2010.04252.x
7. Park J, Sutradhar BC, Hong G, Choi SH, Kim G. Comparison of the cytotoxic effects of bupivacaine, lidocaine, and mepivacaine in equine articular chondrocytes. Vete Anaesth Analges. 2011;38:127-33. https://doi.org/10.1111/j.1467-2995.2010.00590.x

8. Goldstein I, Lind S, Hoffstein S, Weissmann G. Influence of local anesthetics upon human polymorphonuclear leukocyte function in vitro. Reduction of lysosomal enzyme release and superoxide anion production. J Exp Medi. 1977;146:483-94.

https://doi.org/10.1084/jem.146.2.483

9. Chang Y-S, Tseng S-Y, Tseng S-H, Wu C-L. Cytotoxicity of lidocaine or bupivacaine on corneal endothelial cells in a rabbit model. Cornea. 2006;25:590-6.

https://doi.org/10.1097/01.ico.0000220775.93852.02

10. Wu T, Shi Z, Song H, Li Y, Li JH. Cytotoxicity of local anesthetics on rabbit adipose-derived mesenchymal stem cells during early chondrogenic differentiation. Exp Therape Medi. 2018;16:2843-50. https://doi.org/10.3892/etm.2018.6539

11. Breu A, Eckl S, Zink W, Kujat R, Angele P. Cytotoxicity of local anesthetics on human mesenchymal stem cells in vitro. Arthroscopy: J Arthroscopic Related Surg. 2013;29:1676-84.

https://doi.org/10.1016/j.arthro.2013.06.018

12. Oliveira AC, Rodríguez IÁ, Garzón I, Martín-Piedra MÁ, AlfonsoRodríguez CA, García JM, et al. An early and late cytotoxicity evaluation of lidocaine on human oral mucosa fibroblasts. Exp Biol Medi. 2014;239:71-82.

https://doi.org/10.1177/1535370213503274

13. Yagiela JA. Adverse drug interactions in dental practice: Interactions associated with vasoconstrictors: Part V of a series. J Am Dent Assoc. 1999;130:701-09.

https://doi.org/10.14219/jada.archive.1999.0280

14. Liu W, Yang X, Li C, Mo A. Adverse drug reactions to local anesthetics: a systematic review. Oral Surg, Oral Medi, Oral Pathol Oral Radiol. 2013;115:319-27.

https://doi.org/10.1016/j.oooo.2012.04.024

15. Srisatjaluk RL, Klongnoi B, Wongsirichat N. Antimicrobial effect of topical local anesthetic spray on oral microflora. J Dental Anesth Pain Medi. 2016;16:17-24

https://doi.org/10.17245/jdapm.2016.16.1.17

16. Berg JO, Mössner BK, Skov MN, Lauridsen J, Gottrup F, Kolmos HJ. Antibacterial properties of EMLA $®$ and lidocaine in wound tissue biopsies for culturing. Wound Repair Regen. 2006;14:581-85. https://doi.org/10.1111/j.1743-6109.2006.00157.x

17. Pelz K, Wiedmann-Al-Ahmad M, Bogdan C, Otten J-E. Analysis of the antimicrobial activity of local anaesthetics used for dental analgesia. J Medi Microb. 2008;57:88-94.

https://doi.org/10.1099/jmm.0.47339-0

18. Yu S, Wang B, Zhang J, Fang K. The development of local anesthetics and their applications beyond anesthesia. Int J Clin Exp Med. 2019;12: 13203-20.

19. Kaewjiaranai T, Srisatjaluk RL, Sakdajeyont W, Pairuchvej V, 
Wongsirichat $\mathrm{N}$. The efficiency of topical anesthetics as antimicrobial agents: A review of use in dentistry. J Dent Anesth Pain Medi. 2018;18:223-33.

https://doi.org/10.17245/jdapm.2018.18.4.223

20. Aydin O, Eyigor M, Aydin N. Antimicrobial activity of ropivacaine and other local anaesthetics. Eur J Anaesthes. 2001;18:687-94. https://doi.org/10.1097/00003643-200110000-00008

21. Kesici S, Demirci M, Kesici U. Antibacterial effects of lidocaine and adrenaline. Int Wound J. 2019;16:1190-4.

https://doi.org/10.1111/iwj.13182

22. Kesici U, Demirci M, Kesici S. Antimicrobial effects of local anaesthetics. Int Wound J. 2019;16:1029-33.

https://doi.org/10.1111/iwj.13153

23. Shoshani O, Berger J, Fodor L, Ramon Y, Shupak A, Kehat I, et al. The effect of lidocaine and adrenaline on the viability of injected adipose tissue--an experimental study in nude mice. J Drugs in Dermatol: JDD. 2005;4:311-6.

https://doi.org/10.1097/01.PRS.0000153036.71928.30

24. Garisto GA, Gaffen AS, Lawrence HP, Tenenbaum HC, Haas DA. Occurrence of paresthesia after dental local anesthetic administration in the United States. J Am Dent Assoc. 2010;141:836-44. https://doi.org/10.14219/jada.archive.2010.0281

25. Sánchez G, Takara D, Alonso GL. Local anesthetics inhibit Ca-ATPase in masticatory muscles. J Dent Res. 2010;89:372-77. https://doi.org/10.1177/0022034510363220

26. Sharma U. Palatal ulceration: A local anesthetic complication. Indian Journal of Health Sciences and Biomedical Research (KLEU). 2017;10:94.

https://doi.org/10.4103/2349-5006.198598

27. Solanki G. Lidocaine in Dental Science. Int J Biomed Res. 2011;2: 444-50.

https://doi.org/10.7439/ijbr.v2i8.126

28. Haas DA. An update on local anesthetics in dentistry. J Canadian Dent Assoc. 2002;68:546-52.

29. Xu H, Zhang L, Arita H, Hanaoka K. Antimicrobial activity of local anesthetics. Pain Res. 2003;18:19-24.

https://doi.org/10.11154/pain.18.19

30. Razavi BM, Bazzaz BSF. A review and new insights to antimicrobial action of local anesthetics. Eur J Clin Microbi Infect Dise. 2019:1-12.

31. Jarvis WR, Martone WJ. Predominant pathogens in hospital infections. J Antimicrobial Chemother. 1992;29(suppl_A):19-24.

https://doi.org/10.1093/jac/29.suppl_A.19

32. Oza N, Doshi JJ. Angular cheilitis: A clinical and microbial study. Indian J Dent Res. 2017;28:661.

https://doi.org/10.4103/ijdr.IJDR_668_16

33. Yoshikawa TT, Cunha BA. Osteomyelitis in elderly patients. Clin Infect Dise. 2002;35:287-93. https://doi.org/10.1086/341417

34. Bagg J, Sweeney M, Wood KH, Wiggins A. Possible role of Staphylococcus aureus in severe oral mucositis among elderly dehydrated patients. Microbial ecolog health dis. 1995;8:51-6.

https://doi.org/10.3109/08910609509141382

35. Wyman T, Dowden WE, Langeland K. Staphylococcus aureus isolation from a clinically nonexposed root canal. J Endod. 1978;4: 122-8.

https://doi.org/10.1016/S0099-2399(78)80202-7

36. Anthes WH, Blaser MJ, Reller LB. Acute suppurative parotitis associated with anaerobic bacteremia. Am J Clin Pathol. 1981;75:2602.

https://doi.org/10.1093/ajcp/75.2.260

37. Sabatino G, Verrotti A, De Martino M, Fusilli P, Pallotta R, Chiarelli F. Neonatal suppurative parotitis: a study of five cases. Eur J Pediatr. 1999;158:312-4.

https://doi.org/10.1007/s004310051079

38. Brook I. Diagnosis and management of parotitis. Archi OtolaryngolHead \& Neck Surg. 1992;118:469-71.

https://doi.org/10.1001/archotol.1992.01880050015002

39. Smith A, Robertson D, Tang M, Jackson M, MacKenzie D, Bagg J. Staphylococcus aureus in the oral cavity: a three-year retrospective analysis of clinical laboratory data. British dental J. 2003;195:701-3. https://doi.org/10.1038/sj.bdj.4810832

40. Smith A, Jackson M, Bagg J. The ecology of Staphylococcus species in the oral cavity. J Medi Microbi. 2001;50:940-6.

https://doi.org/10.1099/0022-1317-50-11-940

41. Lefevre M, Racedo SM, Denayrolles M, Ripert G, Desfougères T, Lobach AR, et al. Safety assessment of Bacillus subtilis CU1 for use as a probiotic in humans. Reg Toxicolo Pharmacol. 2017;83:54-65. https://doi.org/10.1016/j.yrtph.2016.11.010

42. Schweizer HP. Efflux as a mechanism of resistance to antimicrobials in Pseudomonas aeruginosa and related bacteria: unanswered questions. Genet Mol Res. 2003;2:48-62.

43. Tsay R-W, Siu L, Fung C-P, Chang F-Y. Characteristics of bacteremia between community-acquired and nosocomial Klebsiella pneumoniae infection: risk factor for mortality and the impact of capsular serotypes as a herald for community-acquired infection. Arch of Inter Medi. 2002;162:1021-7.

https://doi.org/10.1001/archinte.162.9.1021

44. Vuong C, Otto M. Staphylococcus epidermidis infections. Microbes infect. 2002;4:481-9.

https://doi.org/10.1016/S1286-4579(02)01563-0

45. Sculley P, Dunley R. Antimicrobial activity of a lidocaine preparation. Anesthesia progress. 1980;27:21.

46. Johnson SM, Saint John BE, Dine AP. Local anesthetics as antimicrobial agents: A review. Surg infect. 2008;9:205-13.

https://doi.org/10.1089/sur.2007.036 